\title{
$2 \%$ CENTRAL AND EAST AFRICAN WATER RESOURCES
}

A REPORT* dealing with the water resources of Central and East Africa has recently been prepared by Prof. F. Debenham, professor of geography at the University of Germbridge, after a stay of about eight months in Afrjed at the suggestion of the Colonial Office. This foport, which will be considered by Colonial poy rernments, is about 110,000 words in length . Hot only is it a most readable discussion of water-resource problems, but also it throws a strong light on problems of economic and social change. The area covered includes the Bechuanaland Protectorate, Northern Rhodesia, the Nyasaland Protectorate, Tanganyika Territory, Kenya and the Uganda Protectorate.

Only the main points of the report can be presented here, and as the recommendations for action on the public-utility scale are of far less immediate importance than those for action at village-level, the power and river-navigation aspects will be briefy dismissed. The plateau topography and waterfalls which guarantee great reserves of water-power have always prevented bulk transport between the coast and the interior. Because future development depends on transport, all forms of which are scarce, the fullest use must be made of certain waterways, and recommendations are included for surveys of seasonal depth, feasibility of canals, etc.

In the provision of domestic water-the first priority - and water for stock and crops, there are difficult problems, mainly human. Most of the area is under strongly seasonal rainfall; and during the months-or weeks-of the rains, the water floods away to waste, whereas, in the subsequent drought, stream flow falls to a trickle or even vanishes below the surface, leaving a 'sand river'. Man, beast and plant suffer severe strain, and the most intense water pollution prevails. Conditions can be greatly improved along countless tributaries by trapping a fraction of the flood flow behind a series of rock or earthen check weirs, each one 100-200 yards upstream of a village. 300,000 gallons should carry a village of 100 persons and 100 cattle through 200 days of drought. To lessen water-borne diseases, the dam and reservoir might be enclosed from man and stock by thornbush. Water would flow ceaselessly from the reservoir by pipe or furrow to the villagers' watering point, then spill on a few yards to the large washing pool and finally to the stock pool and the river bed. In the sand rivers, one subsurface dam, made by trenching across the valiey to the clay bed and nearly filling the trench with clay, can hold up to hundreds of thousands of gallons, according to site. A village could construct its weir or subsurface dam within a few weeks. Porous stream beds usually imply a pastoral economy, and the economic feasibility of piping water from mountain streams deserves study over considerable areas. In streamless regions, boring or well-sinking are the alternatives, and surveys of the ground-water level are needed. Such methods offer the chance of health, of increased productivity, population and trade-the chance of rising above subsistence-level.

However, all plans may fail through apathy in the villages. Prof. Debenham points out that there are

Report on the Water Resources of the Bechuanaland Protectorate, Northern Rhodesia, the Nyasaland Protectorate, Tanganyika Territory, Kenys and the Uganda Protectorate. Colonial Research Publlcation No. 2. By Frank Debenham. Pp. 85. (London: H.M. Stationery Office, 1948.) 108. 6d. net. two refractory problems: the villagers "have a reasonably ordered life, now free from warring, and there is no particular urge to make it easier, or to make it pay better"; further, the unattracted mind sees a bore hole, for example, as "an entirely Government structure" and feels for it "the minimum of responsibility". Progress in these areas awaits countless simple constructions, understood, made by, felt for and maintained by Africans; and the hope must be that African activity will spread from villages which have been induced to try the methods, and where an incentive to increase earning power exists because tastes have been acquired for consumer goods made available by increased production and trade. The establishment of training courses for Africans in the simpler constructions, and even in site selection and the simpler uses of water for village power, is strongly recommended. Trained men would supervise new works under local authorities or Government, or in their own villages. Demonstration water-treatment schemes, which Africans from similar areas could visit, are also required.

Treatment of the swamps so common in the wetter areas is discussed at length. The valley swamps are natural steadiers of flow and their complete drainage would be disastrous. The recommended forms of simple partial drainage under European supervision would, in numberless valleys, provide new farmland and would localize more water in ponds. The major swamps, offering enormous volumes of water which now evaporate, all require elementary surveys involving simple mapping and measurement of discharge, depths, levels, etc.simple but extensive work which already-burdened local officers cannot undertake in years, and without which very little can be started. Prof. Debenham's recommendation - not, of course, limited to swamp surveys--is that scientific expeditions should be encouraged of up to half a dozen young surveyors, engineers, biologists, etc., not yet fully embarked on their careers. A single such party, under a local specialist officer, could, very cheaply and in much less than a year, provide data enabling a general appreciation of the potentialities and treatment needs of the Okavango swamp, as large as East Anglia, or of the irrigation potentialities of several smaller areas.

The report, concerned mainly with problems of water already arrived in valleys or basins or at the ground-water level, and not with the same water while still in or on the soil, only briefly discusses research into water-development problems, which "at first sight . . . seem to be the whole duty of the individual territories". The functions of the African central research bodies are seen, however, to include co-ordination of climatological work, survey promotion, transmission of information between the territories, and much-needed specialist studies such as of the relative evaporation-rates from swamp and open water. However, because land use, operating through the soil and its plant cover, considerably affects the amount and location of water resources, the research required may well be much more extensive and complicated than the report suggests. African land use, especially in areas capable of supporting crops and the denser populations, will change greatly even if gradually, and the effects of these changes on water behaviour can be determined only by long-term studies in selected experimental areas. 
Again, it may be desirable that conditions in a selected series of valleys or sand rivers should, both before and after treatment, be kept under continuous physical and chemical study.

The report is a most welcome production; one would be happier about its general circulation if a shorter version of the whole were available, some. what along the lines of the author's paper "The Water Resources of Central Africa" in a recent number of the Geographical Journal. The conclusions and decisions of the Colonial Governments and the Colonial Office concerning its implementation will be awaited with the liveliest interest in many lands.

2ie

W. D. BRIND

\section{REFORM OF GERMAN HIGHER EDUCATION IN THE BRITISH ZONE OF OCCUPATION}

$\mathrm{T}$ HE Commission set up in the spring of 1948 by the British Military Governor, Sir Brian Robertson, through his edpucational adviser, Mr. Robert Birley, to expminenthe problem of the reform of the German unfreroies and technical high schools in the British 26 he of Occupation, has published its report The membership of the Commission, under troy ch $f$ irmanship of Dr. H. Everling, director of the ferman Co-operative Society, rested on a wide balis of pedagogic, social and intellectual representation; and in addition to the ten German members, the Commission included Lord Lindsay and Prof. J. R. de Salis as non-German members. The member representing the scientific disciplines was Prof. C. F. von Weizsäcker, of Göttingen.

The Commission had complete freedom of action and of expression, and it has produced a correspondingly valuable report, with a long and carefully formulated list of practical recommendations. The keynote of the report is the definition given of what, in the unanimous opinion of the Commission, the goal of higher education should be, namely, "The teaching of truth in the service of the people, of truth won always through a scientific investigation of the facts"; and the report emphasizes that the three operative words in this definition are: the people, investigation and teaching.

Four chief recommendations follow on the practical level : (1) greatly increased facilities for study for students of limited means; (2) promotion of a more intimate contact between the universities and technical high schools and all classes of society (as also the Ministries of Education) through two new advisory or administrative bodies, the 'Hochschulbeirat' and the 'Hochschulrat'; (3) an increase in the scope and in the numbers of the teaching body; (4) furtherance of education and of the unity of culture through a 'studium generale'.

These reforms, in particular (1) and (3), demand increased funds for higher education; and the Commission unanimously and explicitly stresses that the possible argument that Germany cannot afford these luxuries under present conditions is false. The report makes the point that any outlay contemplated under the reforms recommended must be a very small percentage of the total State expenditure; that on the * Gutachten zur Hochschulreform. Pp. v+132.
Studienausschuss fur Hochschulreform, Besenbinderhof 52, 1948.) most mundane level one has to recognize that the fundamental discovery of to-day is the technical application of to-morrow ; that, however, the scientific investigation of facts is a unified discipline; and, finally, that any one branch of scientific investigation must wither if the whole tree of knowledge is not, healthy.

The report devotes special chapters to the four chief recommendations listed above.

(1) Even allowing for the working-class fear, explicitly admitted in the report, that students from the working-class, once having entered a bourgeois university, might desert their class rather than in fluence their new environment, nevertheless the Commission is unanimous in insisting on the desirability of the entry to higher education being made dependent on merit and capability alone, and not on means. Further, the importance for students of making practical contact with life within their chosen profession, while still in statu pupillari, is stressed, not only in the scientific and technical faculties, but also everywhere where a student in the latter end must have contact with the people, be he pastor, lawyer, economist or medical practitioner. Here the Commission recognizes the danger that faces German scholarship in particular of an unsymmetrical absorption in theoretical principles divorced from life.

(2) It is recommended that attached to each university and technical high school in Western Germany there should be : (a) a 'Hochschulbeirat' or advisory committee, widely representative of the life of the community, meeting at least once yearly under the chairmanship of the rector; the 'Beirat' would be purely advisory, its chief aim being to maintain contact between university and public opinion; (b) a 'Hochschulrat' or administrative council, charged with the administrative affairs of the university or technical high school, opposite the Ministry of Education in the 'Land' responsible for the university in question. Each 'Rat' would have six voting members-two elected by the 'Hochschulbeirat', two by the Senate, two by the Ministry of Education-none of whom should be paid servants either of the Ministry or the university; and three non-voting members-an official of the Ministry of Education, the rector, and an elected representative of the teaching body. The 'Rat' would be steered by a president, appointed for life by all nine members of that body.

(3) With regard to increasing the teaching body in size and scope, by far the most important recom. mendation is for the foundation in each faculty of every university of new positions carrying a purely pedagogic assignment and responsibility-'Studiendozenten' and 'Studienprofessoren'. The report admits quite freely that the Commission is recommending here a break with the Humboldt tradition of Lern- and Lehr-freiheit of the nineteenth century in the German universities - a tradition which the report nevertheless recalls with pride. These new teaching posts would carry the status and privileges of the traditional scholarly 'Dozent' and 'Professor'; but the men would be chosen for their pedagogic aptitude and enthusiasm, rather than for their eminence in a particular scholarly discipline.

(4) The recommendation of the Commission that the universities and technical high schools experiment with a 'studium generale', intensively in the first two semesters, less intensively in the third and fourth semesters, arises from the conviction expressed 